\title{
Pemanfaatan Pembangkit Listrik Tenaga Surya Pada Gedung Bertingkat
}

\author{
Tri Joko Pramono ${ }^{1}$; Erlina ${ }^{2}$; Zainal Arifin ${ }^{3}$; Jef Saragih ${ }^{4}$ \\ 1, 2,3,4 Institut Teknologi PLN \\ 'tri.joko@itpln.ac.id \\ 2erlina@itpln.ac.id \\ 3ainal_pln@yahoo.com \\ ${ }^{4}$ jeffturnip18@gmail.com
}

\begin{abstract}
Solar Power Plant is one of the New Renewable Energy power plants. Solar panels can produce unlimited amounts of electrical energy directly taken from the sun, with no rotating parts and no fuel. In this study are optimize solar power plants using hybrid systems with electricity companies and the use of semi-transparent solar panels in high rise buildings to meet the burden of the building. The research will discussed about use of solar power plants using semi-transparent solar panels in multi-storey buildings. The solar panel used for the facade is a semi-transparent solar panel makes its function become two, that is to produce electrical energy as well as glass through which sunlight and can see the view outside the building without reducing the building's aesthetic value. In this study is the value of solar radiation taken from west is the lowest value in November $1.4 \mathrm{Kwh}$ can produce energy PLTS 3,855 Kwh and the highest solar radiation in July amounted to $3.75 \mathrm{Kwh}$ can produce energy PLTS $10.331 \mathrm{Kwh}$. From the utilization of this PLTS system, Performance Ratio of $85 \%$ was obtained using study of 36 panels on the 3rd to 5th floors, this system can be said to feasible.
\end{abstract}

Keywords: PLTS, hybrid system, Performance Ratio

\begin{abstract}
ABSTRAK
Pembangkit Listrik Tenaga Surya merupakan salah satu pembangkit listrik Energi Baru Terbarukan. Panel surya dapat menghasilkan energi listrik dalam jumlah yang tidak terbatas langsung diambil dari matahari, tanpa ada bagian yang berputar dan tidak memerlukan bahan bakar. Adapun tujuan yang akan dicapai dalam penelitian ini mengoptimalkan pembangkit listrik tenaga surya menggunakan sistim hibrid dengan perusahaan listrik dan penggunaan panel surya semi transparan pada gedung bertingkat untuk memenuhi beban gedung tersebut. Dalam penelitian ini akan dibahas tentang pemanfaatan PLTS dengan menggunakan panel surya semi transparan pada gedung bertingkat. Panel surya yang dipakai untuk fasad yaitu panel surya semi-transparan yang membuat fungsinya menjadi dua yaitu menghasilkan energi listrik sekaligus kaca tempat masuknya cahaya matahari dan dapat melihat pemandangan diluar gedung tanpa mengurangi nilai estetika gedung. Pada penelitian ini terdapat nilai radiasi matahari diambil dari arah barat yaitu nilai terendah bulan November 1,4 Kwh yang dapat menghasilkan energi PLTS 3,855Kwh dan tertinggi radiasi matahari bulan Juli sebesar 3,75 Kwh yang dapat menghasilkan energi PLTS 10,331 Kwh. Dari pemanfaatan sistem PLTS ini diperoleh Performance Ratio sebesar 85\% dengan menggunakan studi 36 panel pada lantai 3 sampai lantai 5 maka sistem ini dapat dikatakan layak untuk direalisasikan.
\end{abstract}

Kata kunci: PLTS, Sistim hibrid, Performance Ratio 


\section{KILAT}

Vol. 9, No. 1, April 2020, P-ISSN 2089-1245, E-ISSN 2655-4925

DOI: https://doi.org/10.33322/kilat.v9i1.888

\section{PENDAHULUAN}

Energi listrik yang dihasilkan panel surya sangat dipengaruhi oleh intensitas cahaya matahari yang diterima oleh sistem. Intensitas cahaya matahari juga di pengaruhi oleh besarnya radiasi yang sampai pada panel surya, seperti pengaruh atmosfer yaitu debu, uap air, dan oleh gas-gas lainnya berupa bayang bayang (shaded). Dari pengaruh atmosfer tersebut menentukan besarnya daya dari energi sumber cahaya yang sampai pada seluruh permukaan panel surya. Semakin besar energi cahaya yang di serap panel surya maka semakin besar energi listrik yang dihasilkan. Maka dapat dihitung efisiensi photovoltaic ditinjau dari variasi bayangan pada panel surya. Dalam penelitian ini akan dibahas tentang pemanfaatan PLTS dengan menggunakan panel surya semi transparan pada gedung bertingkat yaitu Rumah Sakit X.

Vocabullary Education Develocment Center (VEDC) Malang pada tahun 2008,melakukan penelitian untuk menganalisis secara teknis dan ekonomis penerapan sistem Photovoltaik sebagai penyedia daya dengan beban pertamanan di Vocabullary Education Develocment Center Malang, Dari hasil percobaan dan analisis didapatkan prosentase jatuh tegangan terbesar pada saat cuaca mendung sebesar 4,76\% dan jatuh tegangan terkecil pada keadaan cuaca cerah sebesar 4,17\%.

Dalam penelitian lain yang dilakukan di Hong Kong, Fung dan Yang (2008) menyelidiki kinerja termal Building-Intergated Photovoiltaic (BIPV), yang menjaga agar cahaya matahari tetap masuk kedalam ruangan gedung.

Chow et al. (2010) meneliti sebuah studi eksperimental menggunakan kamar uji di Hong Kong yang dilakukan mengevaluasi kinerja energi dari tempat yang berbeda yang berkonfigurasi dengan sistem kaca fotovoltaik. Hasil penelitian menunjukkan bahwa panel surya semi-transparan dengan $10 \%$ transmitansi secara efektif dapat mengurangi radiasi matahari langsung dan silau yang berlebihan. Pada pemakaian pendingin ruangan, terjadi penurunan konsumsi listrik dari $26 \%$ hingga $82 \%$.

\section{METODE PENELITIAN}

Perencanaan Lokasi yang diambil untuk pembangunan PLTS ini yaitu di gedung Rumah Sakit X yang berada di Jawa Barat dengan titik koordinat 6 ${ }^{\circ} 18^{\prime} 12^{\prime \prime}$ Lintang Selatan (LS) 107¹6'39"E.306 Bujur Timur (BT). Lokasi ini diambil karena gedung rumah sakit berada di suatu perkotaan yang padat penduduk, lahan yang cukup luas diperlukan jika menginginkan pembangunan PLTS.

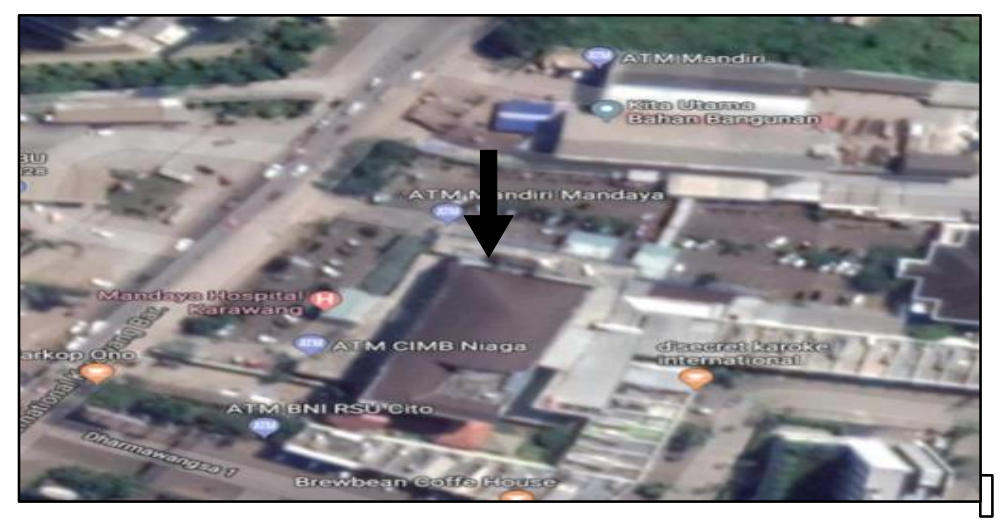

Gambar 1. Lokasi Gedung Rumah Sakit X

Semua kaca gedung dimulai dari lantai 2 sampai lantai 5 hingga berjumlah 194 bidang kaca gedung. Dalam usulan ini peneliti akan memasang panel surya pada lantai 3 dan lantai 4 gedung dengan total kaca awal atau rumah sakit yang akan diubah sebanyak 48 kaca. 
Pada penelitian ini menggunakan tipe panel surya semitransparan yang memungkinkan kita untuk melihat pemandangan diluar kaca jendela. Semakin transparan daya yang dihasilkan panel surya akan semakin kecil. Panel surya semi-transparan dari Sun Well Solar dengan warna orange yang transparansinya $20 \%$, rated power $90 \mathrm{~W}$ dengan temperatur minimum $-20^{\circ} \mathrm{C}$ dan maksimal $85^{\circ} \mathrm{C}$. Untuk panel surya semi transparan dari Sun Well Solar hanya tersedia 1 warna, yaitu warna orange, untuk merek yang lain tersedia juga panel surya semi transparan dengan berbagai warna tanpa mempengaruhi daya yang dihasilkan, salah satunya merek Panel surya Solarfirst dengan ketersediaan warna merah, kuning, dan hijau.

Tabel 1. Spesifikasi Panel Surya

\begin{tabular}{|c|c|c|}
\hline \multicolumn{2}{|c|}{ Property } & Physical Specification \\
\hline \multicolumn{2}{|l|}{ Active Material of Cell } & Amorphous Silicon \\
\hline \multicolumn{2}{|l|}{ Junction Type of Cell } & Single Junction \\
\hline \multicolumn{2}{|c|}{ Material for Encapsulation } & Polyvinylbutyral (PVB), thickness: $0.76 \mathrm{~mm}$ \\
\hline \multicolumn{2}{|l|}{ Front Cover } & Float glass, thickness: $3.2 \mathrm{~mm}$ \\
\hline \multicolumn{2}{|l|}{ Back Cover } & Float glass, thickness: $3.2 \mathrm{~mm}$ \\
\hline \multicolumn{2}{|l|}{ Wiring Material } & Tin \& silver coated copper ribbon, thickness: $0.1 \mathrm{~mm}$ \\
\hline \multirow{2}{*}{ Junction Box/IP Class } & By pass Diode & Yes \\
\hline & IP Class & IP 67 \\
\hline \multicolumn{2}{|c|}{ Junction Box Cable Length } & Upward , $800 \mathrm{~mm}(+) / 600 \mathrm{~mm}(-)$ \\
\hline \multicolumn{2}{|l|}{ Connecting Cable/Plug } & $\begin{array}{l}\text { Rated voltage : } 1000 \text { D.C. Plug/Socket : MC4 } \\
\text { compatible, diam. } 4 \mathrm{~mm} \text { Cable cross section : } \\
2.5 \mathrm{~mm} 2\end{array}$ \\
\hline
\end{tabular}

\section{HASIL DAN PEMBAHASAN}

\subsection{Radiasi yang Didapat Dari Sisi Barat Gedung Rumah Sakit $X$}

Untuk mengetahui besar radiasi terbaik dari berbagai sisi maka diketahui

$$
\begin{aligned}
\text { Azimuth }: 0^{\circ} & =\text { Timur } & -90^{\circ}=\text { Utara } & \text { Inclination }=90^{\circ} \\
90^{\circ} & =\text { Selatan } & 180^{\circ}=\text { Barat } &
\end{aligned}
$$

Berikut adalah hasil radiasi setahun yang didapat dari aplikasi web JRC UE dari berbagai arah dengan inclination $90^{\circ}$.

Tabel 2. Radiasi matahari yang didiapat dalam satu tahun.

\begin{tabular}{|l|c|c|c|c|c|c|c|c|c|c|c|c|}
\hline \multicolumn{1}{|c|}{ Bulan } & Jan & Feb & Mar & Apr & Mai & Jun & Jul & Agt & Sep & Okt & Nov & Des \\
\hline $\begin{array}{l}\text { Barat } \\
\mathrm{kWh} / \mathrm{m}^{2} \text {.day }\end{array}$ & 1,5 & 1,6 & 1,79 & 2,65 & 3,14 & 3,62 & 3,75 & 3,45 & 2,38 & 1,5 & 1,4 & 1,5 \\
\hline
\end{tabular}

Untuk melihat lamanya penyinaran dalam satu hari dapat dilihat radiasi pada rencana pembangunan yang akan dipasang panel surya. Berikut adalah radiasi satu hari arah barat gedung Rumah Sakit X pada bulan Desember. 


\section{KILAT}

Vol. 9, No. 1, April 2020, P-ISSN 2089-1245, E-ISSN 2655-4925

DOI: https://doi.org/10.33322/kilat.v9i1.888

Tabel 3. Radiasi matahari dalam sehari di bulan Desember

\begin{tabular}{|c|c|c|c|c|c|}
\hline No & Waktu & $\begin{array}{c}\text { Radiasi rata-rata } \\
\text { W/m }\end{array}$ & No & Waktu & $\begin{array}{c}\text { Radiasi rata-rata } \\
\text { W/m }\end{array}$ \\
\hline 1 & $6: 30$ & 201 & 14 & $12: 00$ & 111 \\
\hline 2 & $7: 00$ & 461 & 15 & $12: 30$ & 111 \\
\hline 3 & $7: 30$ & 503 & 16 & $13: 00$ & 110 \\
\hline 4 & $8: 00$ & 595 & 17 & $13: 30$ & 109 \\
\hline 5 & $8: 30$ & 602 & 18 & $14: 00$ & 102 \\
\hline 6 & $9: 00$ & 580 & 19 & $14: 30$ & 98 \\
\hline 7 & $9: 30$ & 561 & 20 & $15: 00$ & 82 \\
\hline 8 & $10: 00$ & 467 & 21 & $15: 30$ & 75 \\
\hline 9 & $10: 30$ & 434 & 22 & $16: 00$ & 48 \\
\hline 10 & $10: 00$ & 320 & 23 & $16: 30$ & 48 \\
\hline 11 & $10: 30$ & 279 & 24 & $17: 00$ & 36 \\
\hline 12 & $11: 00$ & 112 & 25 & $17: 30$ & 36 \\
\hline 13 & $11: 30$ & 112 & 26 & $18: 00$ & 36 \\
\hline
\end{tabular}

Dari tabel diatas dpaat dilihat bahwa radiasi terbesar berada dari jam 6 pagi kemudian semakin naik hingga jam 08.30 siang dan kembali menurun hingga jam 18 sore. Hal ini bearti pemasangan panel surya akan di letakan pada sisi yang menghadap ke barat dengan azimuth -90 dan inclination 90, karena kondisi gedung Rumah Sakit X dari arah Timur terhalang oleh gedung lain sedangkan pada arah utara dan selatan gedung lebih sedikit peluang untuk mendapatkan radiasi matahari.

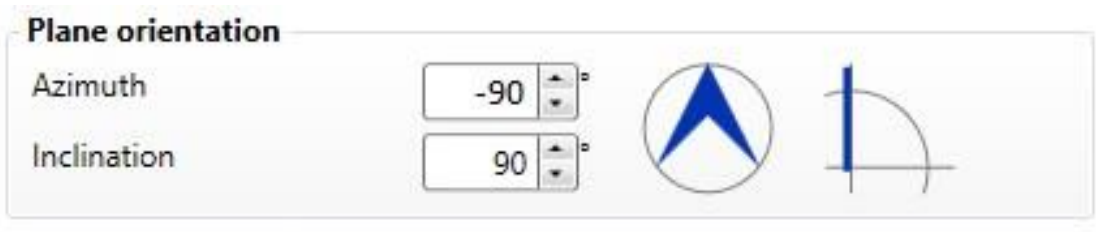

Gambar 2. Plane Orientation Panel Surya.

\subsection{Pangaturan besar Panel surya pada Kaca Fasad Gedung Rumah Sakit $X$}

Pada rumah sakit $\mathrm{X}$ setiap lantai memiliki sekat kaca yang tertutup dengan warna putih dengan ukuran yang berbeda dengan kaca jendela yang ada pada setiap lantai tetapi Hal ini dapat dimanfaatkan juga untuk peletakan panel surya.

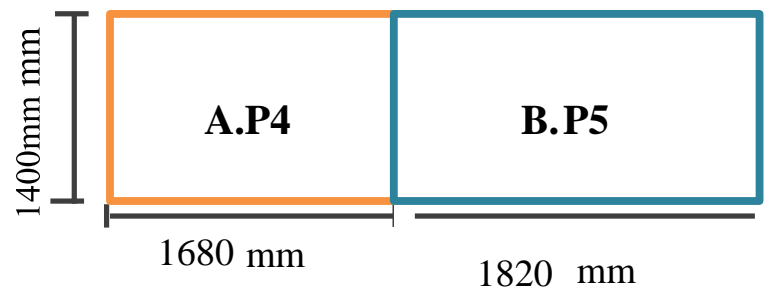

Gambar 3. Ukuran Kaca Fasad Gedung Rumah Sakit X Lantai 3 Dan Lantai 4 


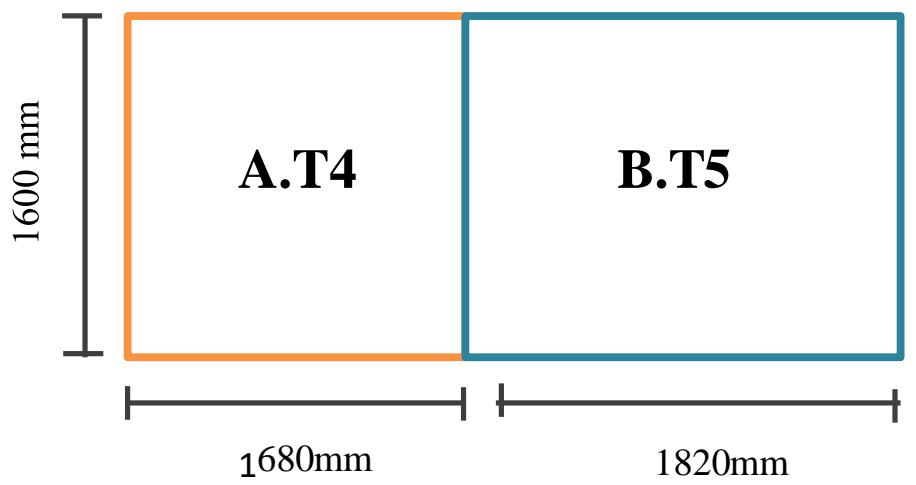

Gambar 4. Ukuran Kaca Fasad Gedung Rumah Sakit X Lantai 5

Dilihat ukuran kaca jendela yang ada di rumah sakit X, maka panjang dan lebar panel surya harus disesuaikan dengan kaca tersebut dapat diatur sebagai berikut:

1. Dengan ukuran kaca jendela jika kaca A.P4 di gabungkan dengan kaca B.P5 maka $168 \mathrm{~cm}$ (Panjang kaca A.P4) $+182 \mathrm{~cm}$ (panjang kaca B.) $\times 6$ Bidang = $2,100 \mathrm{~cm}$ atau 21 meter Kaca. Dengan tinggi panel surya yaitu $140 \mathrm{Cm}$ (Lebar Panel Surya) -110 (tinggi Kaca jendela rumah sakit) $=30 \mathrm{~cm}$

2. Dengan ukuran kaca jendela jika kaca A.T4 di gabungkan dengan kaca B.T5 maka $168 \mathrm{~cm}$ (Panjang kaca A.T4) $+182 \mathrm{~cm}$ (panjang kaca B.) x 6 Bidang 2,100 cm atau 21 meter

Kaca. Dengan tinggi panel surya yaitu 160 Cm (Lebar Panel Surya) -110 (tinggi Kaca jendela rumah sakit) $=50 \mathrm{~cm}$

Dari sisa tinggi panel surya tersebut maka kaca A dapat dipindahkan ke atas sehingga kaca yang ada masih dapat di pakai. Berikut adalah gambar pengaturan panel surya pada 1 bidang kaca jendela.

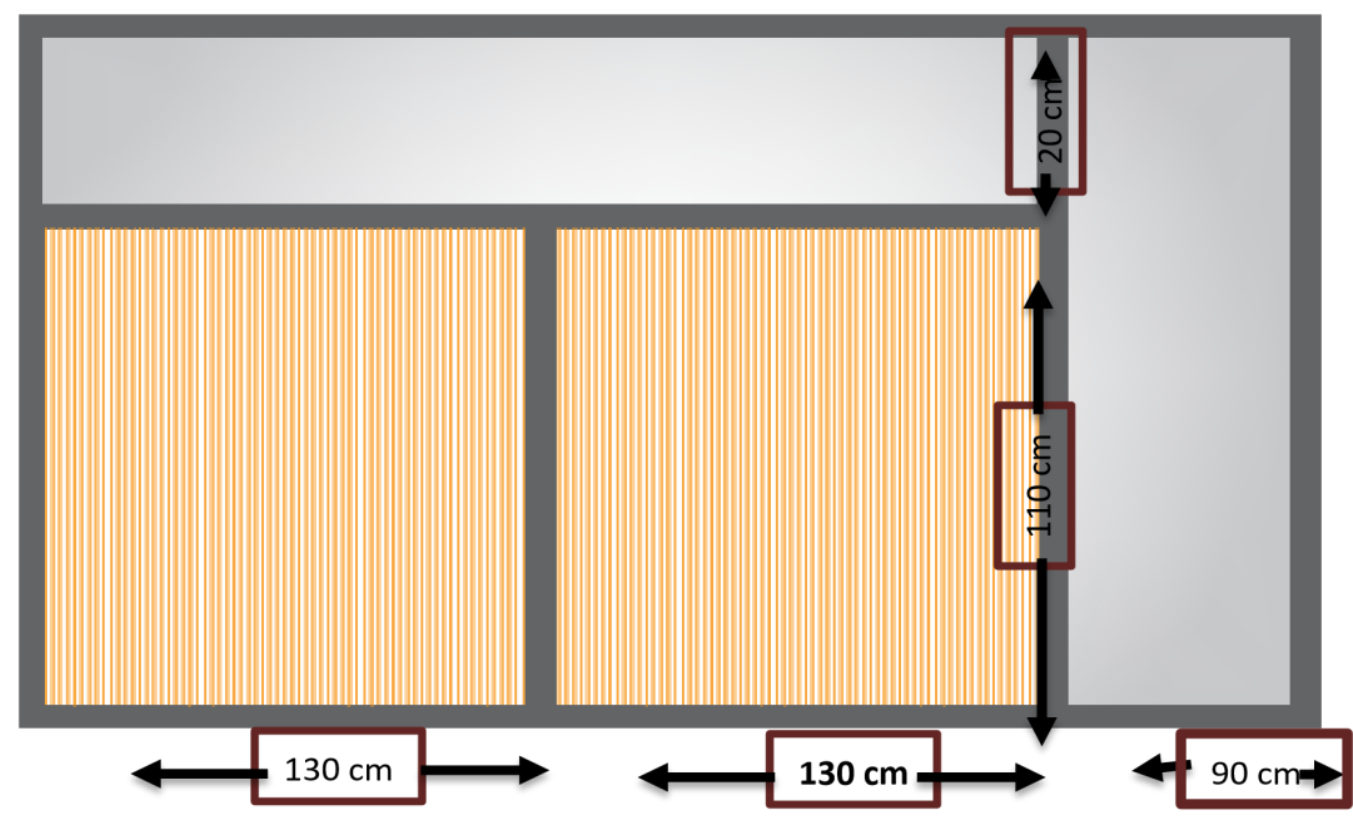

Gambar 5. Pengaturan Panel Surya Pada Satu Bidang Kaca Jendela Lantai 3 Dan Lantai 4 


\section{KILAT}

Vol. 9, No. 1, April 2020, P-ISSN 2089-1245, E-ISSN 2655-4925

DOI: https://doi.org/10.33322/kilat.v9i1.888

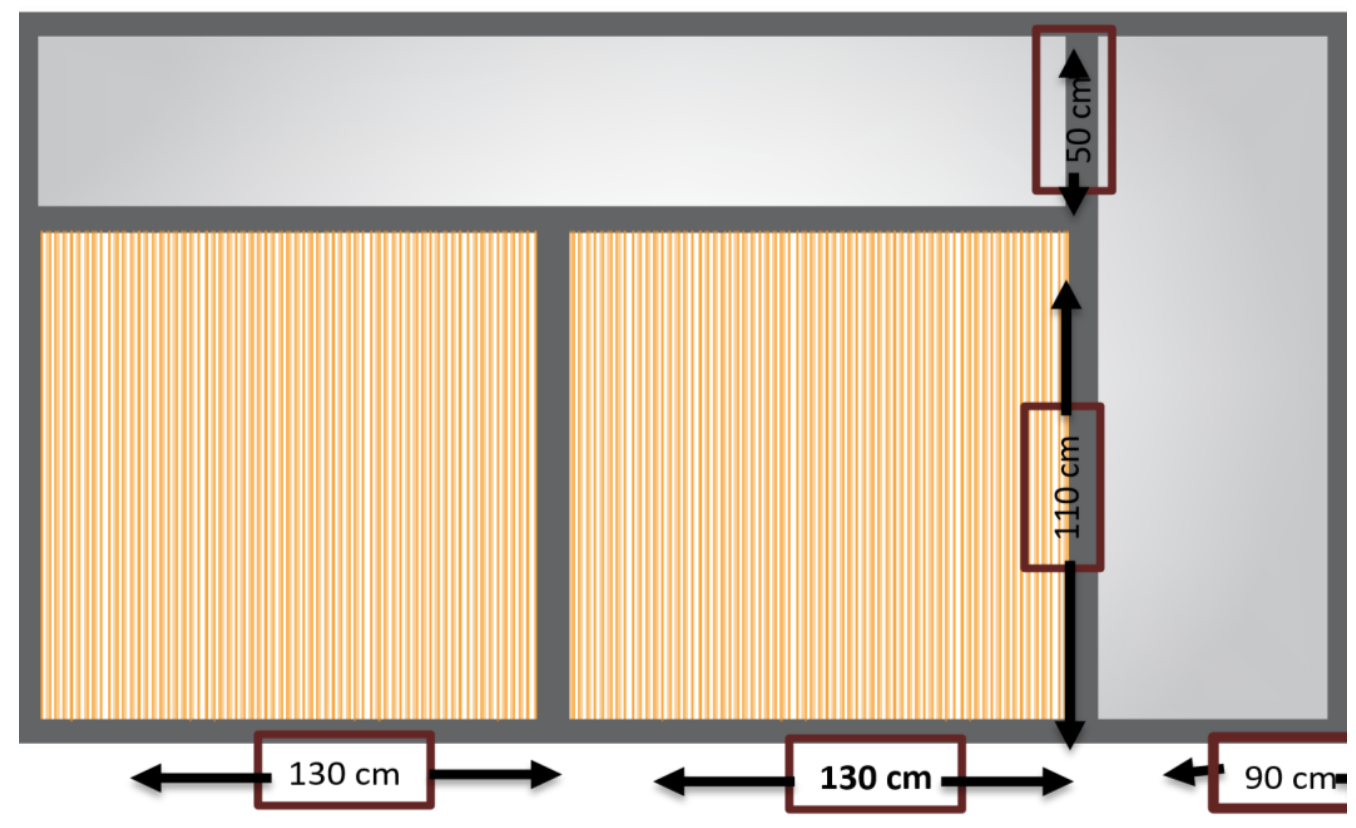

Gambar 6. Pengaturan Panel Surya Pada Satu Bidang Kaca Jendela Lantai 5

Dari setiap bidang dipasang 2 panel pada gedung rumah sakit terdapat 6 bidang sehingga dalam satu lantai terdapat 2 panel surya lantai Panel surya dapat dipasang 2 panel surya disetiap satu peletakan kaca jendela. Jadi setiap lantai dapat dipasang 12 panel surya pada setiap pengganti kaca jendela. Kemudian untuk setiap sekat setiap lantai gedung dengan ukuran yang sama dengan kaca jendela dapat pula dipasang panel surya. Jadi setiap lantai dari lantai 3 sampai lantai 5 yang dapat dipasang panel surya sebanyak :

Jumlah panel surya $=3$ lantai $\times 2 \times 6$ panel surya $=36$ Panel surya

Jadi banyaknya panel surya yang dapat dipasang yaitu 36 panel surya.

\subsection{Pengaturan Seri-Paralel Panel Surya}

1. Secara seri minimal

Min. Modul seri per string $=\frac{150 \mathrm{~V}}{137 \mathrm{~V}}=1,09 \approx 1$ panel

2. Secara seri maximal

Max.. Modul seri per string $=\frac{1000 \mathrm{~V}}{103 \mathrm{~V}}=9,7 \approx 10$ panel

3. Secara paralel

Max.. paralel $=\frac{33 \mathrm{~A}}{0,90 \mathrm{~A}}=36,67 \approx 37$ panel

Perhitungan diatas menjelaskan bahwa batas tegangan dan arus input DC ke inverter dari panel surya harus di batasi sesuai dengan spesifikasi inverter. Dan hal ini dapat di atur dengan banyaknya seri atau paralel panel surya yang akan dipasang. Dari perhitungan diatas maka pengaturan yang ditentukan yaitu

12 PV (Dihubung Paralel) $\times 3$ PV (Dihubung seri) $=36$ Panel surya

Besar daya $=36 \mathrm{PV} \times 90 \mathrm{Wp}=3240 \mathrm{Watt}$. 
Pemasangan dibagi menjadi 3 blok. Setiap blok terdiri dari 12 paralel yang masing masing paralel memiliki 3 seri. 3 blok ini kemudian dihubungkan dengan dipasangan paralel. Maka perhitungan arus dan tegangannya sebagai berikut :

Blok \#1

Besar arus $=$ arus panel surya $\mathrm{x}$ jumlah paralel panel surya

Besar arus $=0,90 \mathrm{~A} \times 12=10,8 \mathrm{~A}$

Besar Tegangan $=$ Vmp $\mathrm{x}$ jumlah seri panel surya pada setiap paralel

Besar Tegangan $=103 \mathrm{~V}$ x $3=309 \mathrm{~V}$

Blok \#2

Besar arus $=$ arus panel surya $\mathrm{x}$ jumlah paralel panel surya

Besar arus $=0,90 \mathrm{~A} \times 12=10,8 \mathrm{~A}$

Besar Tegangan $=$ Vmp $\mathrm{x}$ jumlah seri panel surya pada setiap paralel

Besar Tegangan $=103 \mathrm{~V} \times 3=309 \mathrm{~V}$

V Blok \#1 dan blok \#2 terhubung paralel maka arus yang bertambah dan tegangan tetap. Jadi besar arus keseluruhan adalah

$$
\begin{aligned}
\mathrm{A}_{\text {total }} & =\text { Arus Blok \#1+ Arus Blok \#2 } \\
& =10.8 \mathrm{~A}+10.8 \mathrm{~A}=21.6 \mathrm{~A}
\end{aligned}
$$

\subsection{Menghitung Besar Daya Keluaran PLTS}

Pada perencanaan pembangunan PLTS maka tidak akan lepas dari rugi rugi sistem yang mempengaruhi daya yang dihasilkan. Rugi-rugi keseluruhan sistem PLTS dianggap 15\% karena keseluruhan komponen sistem yang digunakan masih baru (Bien, Kasim, \& Wibowo, 2008:41 dalam bukunya Mark Hankins, 1991: 68), rugi-rugi ini sudah termasuk losses kabel, inverter, panel surya (losses yang dipengaruhi dari debu dan temperature) sehingga besar energi dari panel surya adalah sebesar:

$$
36 \text { panel surya } \times 90 \text { Watt }=3240 \text { Watt }=3,240 \mathrm{~kW}
$$

Dengan rugi-rugi $15 \%$ maka keluaran dari PLTS yaitu

$$
\begin{aligned}
& \mathrm{Pi}=\text { besar kapasitas terpasang } \times 15 \%=3240 \times 15 \%=486 \text { Watt } \\
& \text { Ptotal }=3240 \text { Watt }-486 \mathrm{Watt}=2754 \mathrm{Watt}=2,754 \mathrm{~kW}
\end{aligned}
$$

Rating modul surya berdasarkan kapasitas modul yang terpasang sudah dikurangi dengan rugi-rugi besarnya $2.754 \mathrm{~kW}$. Berikut ini akan dianalisa energi yang dihasilkan oleh modul surya berkaitan dengan data radiasi matahari yang terendah danyang tertinggi.

Apabila data yang digunakan adalah data radiasi matahari yang terendah, yaitu 2,21 maka energi yang dihasilkan modul dapat dihitung sebagai berikut:

$$
\begin{aligned}
\text { Pout } & =\text { Pi } \times \text { Radiasi matahari } \\
& =2754 \text { Watt } \times 1,4 \mathrm{Kwh} \\
& =3855.6 \mathrm{Wh} \approx 3,855 \mathrm{kWh} \\
& \text { Energi yang dihasilkan modul adalah } 3,855 \mathrm{kWh} .
\end{aligned}
$$

Apabila data yang digunakan adalah data radiasi matahari yang tertinggi, yaitu 3,75.

Berdasarkan persamaan maka energi yang dihasilkan modul dapat dihitung sebagai berikut:

$$
\begin{aligned}
\text { Pout } & =P i \times \text { Radiasi matahari } \\
& =2755 \mathrm{Watt} \times 3,75 \mathrm{kWh} \\
& =10331,25 \mathrm{Wh} \approx 10,331 \mathrm{kWh}
\end{aligned}
$$




\section{KILAT}

Vol. 9, No. 1, April 2020, P-ISSN 2089-1245, E-ISSN 2655-4925

DOI: https://doi.org/10.33322/kilat.v9i1.888

Tabel 4. Perbandingan Tingkat Radiasi Matahari Terendah Dan Tertinggi Dalam Satu Tahun.

\begin{tabular}{|c|c|c|}
\hline Tingkat Radiasi & $\begin{array}{c}\text { Radiasi matahari } \\
(\mathbf{k W h})\end{array}$ & $\begin{array}{c}\text { Energi yang dihasilkan } \\
\text { PLTS }(\mathbf{k W h})\end{array}$ \\
\hline Terendah & 1.4 & 3,855 \\
\hline Tertinggi & 3,75 & 10,331 \\
\hline
\end{tabular}

Apabila ingin dilihat dari energi yang dihasilkan rata-rata pertahun maka digunakan radiasi rata-rata atau dikenal dengan nama Peak Sun Hour (PSH) dengan besar PSH yaitu 2,35h. Sehingga energy yield per tahun adalah:

Energy output PV $=$ Pi x PSH

$$
=2755 \text { Watt } x 2.35 \mathrm{~h}=6474,25 \mathrm{kWh}
$$

1 tahun $=365$ hari

Energi yield $=$ energi output $\mathrm{x} 365$ hari

Energi yield $=6,474 \mathrm{kWh} \times 365$ hari $=2363,10 \mathrm{kWh} /$ tahun

\subsection{Menghitung Jumlah Baterai}

Baterai yang digunakan $12 \mathrm{~V}-100 \mathrm{Ah}$

Disusun Seri untuk mendapatkan tegangan 48 V, n : 4 buah

Kapasitas penyimpanan baterai (KPLB)

$$
\begin{aligned}
& K P L B=48 \times 100 \mathrm{Ah}=4800 \mathrm{Wh} \\
& \text { Jumlah baterai }=\frac{\text { Potensi Energi } / \text { KPLB }}{50 \%} \\
& \text { Jumlah baterai }=\frac{6474 \mathrm{Wh} / 4800}{50 \%}=2,69 \approx 3 \text { buah baterai }
\end{aligned}
$$

Dimana : 50\% adalah menggunakan asumsi DOD (Deep Of Discharge) pada baterai

\subsection{Performance Ratio}

$$
\begin{aligned}
\text { Daya simpan listrik baterai } & =48 \mathrm{~V} \times 100 \mathrm{Ah} \times 3 \text { buah baterai } \\
& =14400 \mathrm{Wh}=14.4 \mathrm{kWh}
\end{aligned}
$$

Performance ratio (PR) adalah ukuran suatu kualitas sistem dilihat dari energi tahunan yang dihasilkan sebenarnya. Sistem dapat dikatakan layak secara teknis bila PR nya sekitar 70\% - 90\%. Dalam menghitung performance ratio dari sistem PLTS dapat menggunakan rumus perhitungan berikut ini :

$$
\begin{aligned}
& P R=\frac{E \text { yield }}{\text { Eideal }}, E \text { ideal }=P \text { array STC } \times \text { Htilt } \\
& \text { Htilt }=P S H \times 365=\left(2,35 \mathrm{~h} \times \frac{1000 \mathrm{~W}}{\mathrm{~m} 2}\right) \times 365 \text { hari } \\
& =857.750 \mathrm{kWh} / \mathrm{m} 2
\end{aligned}
$$

Maka rata-rata radiasi selama setahun berdasarkan pada saat PSH $(2,35 \mathrm{~h})$ adalah:

Energi ideal $=$ daya spesifikasi modul surya $\mathrm{x}$ jumlah modul $\mathrm{x}$ Hitlt

Energi ideal $=90 \mathrm{Wp} \times 36$ modul $\times 857.750 \frac{h}{\text { tahun }}=2779110 \mathrm{Wh} /$ tahun

Energi ideal $=2779,110 \mathrm{kWh} /$ tahun

Sehingga diperoleh PR, sebesar : 


$$
P R=\frac{E \text { yield }}{\text { E ideal }}=\frac{2363,10 \mathrm{kWh} / \text { tahun }}{2779,110 \mathrm{kWh} / \text { tahun }}=0,85=85 \%
$$

Dari perancangan sistem PLTS ini diperoleh Performance Ratio sebesar 85\% maka sistem ini dapat dikatakan layak untuk direalisasikan.

\section{KESIMPULAN DAN SARAN}

Dari hasil pembahasan dalam penelitian ini dapat di ambil beberapa kesimpulan sebagai berikut:

1. Peletakan panel surya yang tepat dengan orientasi vertikal pengganti jendela pada gedung Rumah Sakit X dilihat dari radiasi yang adalah kearah barat.

2. Panel surya yang dihubungkan seri-paralel berjumlah keseluruhan 36 panel surya yang dapat menghasilkan daya keluaran bersih sebesar $2,754 \mathrm{~kW}$ dan daya rata-rata perharinya sebesar 6,5 kWh sehingga energi yang dihasilkan sebesar 2363,1 kWh/tahun.

3. Performance Ratio ( PR ) pada PLTS dengan panel surya transparan pengganti jendela adalah sebesar $85 \%$. Sistem dapat dikatakan layak bila PR nya melebihi $70 \%$. Maka sistem ini dapat dikatakan layak secara teknis untuk dipasang pada gedung Rumah Sakit X.

\subsection{Saran}

Penempatan Panel surya haruslah tepat karena akan mempengaruhi besar radiasi yang didapat sekaligus mempengaruhi daya output dari panel surya.

\section{UCAPAN TERIMAKASIH}

Penulis mengucapkan terima kasih kepada LPPM STT PLN yang telah memberi dukungan yang membantu pelaksanaan penulisan artikel.

\section{DAFTAR PUSTAKA}

[1] Azhar Ghazali, Elias Salleh, Lim Chin Haw, Kamaruzzaman Sopian and Sohif Mat. (2016). Photovoltaic Façade in Malaysia: The Development and Current Issues. Solar Energy Research Institute (SERI), Universiti Kebangsaan Malaysia, 43600 Bangi, Selangor, Malaysia

[2] Baharuddin. (2013). Analisis Perolehan Radiasi Matahari pada Berbagai Orientasi Bidang Vertikal. Laboratorium Sains dan Teknologi Bangunan, Jurusan Arsitektur, Fakultas Teknik, Universitas Hasanuddin.

[3] Fung, T. Y. Y. \& Yang, H. (2008). Study on thermal performance of semitransparent buildingintegrated photovoltaic glazings. Energy and Buildings, 40, 341-350.

[4] Hankins, Mark. (1991). Small Solar Electric Systems for Africa" Motif Creative Arts, Ltd. Kenya.

[5] Hafidz Mohammad. (2016). Pembangkit Listrik Tenaga Surya (PLTS). Basic Training For Solar System, Sekolah Tinggi Teknik-PLN.

[6] Ng Poh Khai. (2014). Semi-Transparent Building-Integrated Photovoltaic (Bipv) Windows ForThe Tropics. Thesis, Department Of Architecture National University Of Singapore.

[7] Pangestuningtyas D.L, Hermawan, And Karnoto. (2013). Analisis Pengaruh Sudut Kemiringan Panel Surya Terhadap Radiasi Matahari Yang Diterima Oleh Panel Surya Tipe Larik Tetap. Jurusan Teknik Elektro, Universitas Diponegoro Semarang. 


\section{KILAT}

Vol. 9, No. 1, April 2020, P-ISSN 2089-1245, E-ISSN 2655-4925

DOI: https://doi.org/10.33322/kilat.v9i1.888

[8] Pangestuningtyas D.L*), Hermawan, And Karnoto. (2013). Analisis Pengaruh Sudut Kemiringan Panel Surya Terhadap Radiasi Matahari Yang Diterima Oleh Panel Surya Tipe Larik Tetap. Jurusan Teknik Elektro, Universitas Diponegoro Semarang.

[9] Santoso, Denny. (2008). Strategi Aplikasi Sel Surya pada Perumahan dan Bangunan Komersial, Jurusan Teknik Arsitektur, Fakultas Teknik Sipil dan Perencanaan - Universitas Kristen Petra. Surabaya. 